\title{
Archetypal Posturing of Soyinka's Stylistic Modes in the Trials of Brother Jero
}

\author{
Nii Okain Teiko \\ University of Professional Studies Accra (UPSA) \\ nii.teiko@upsamail.edu.gh
}

DOI: http://doi.org/ 10.36892/ijlls.v3i4.689

\begin{tabular}{ll}
$\begin{array}{l}\text { Received: } \\
\text { 30/08/2021 }\end{array}$ & Abstract \\
Accepted: & portraiture of the arshetypal trickster hero, as utilized in some of his comic \\
$22 / 11 / 2021$ & plays, demonstrate a genius whose creative works anchor both the collective \\
\hline Keywords: & universal literary tradition and a domesticated form that defines his uniqueness. \\
Archetype, & Drawing interpretive insights from Frye's archetypal criticism and the Jungian \\
Eshu, & psychology, this essay examines how Soyinka appropriates the archetypal \\
Gull-Knave Pattern, & figure as a monumental image in the play, The Trials of Brother Jero, and how \\
Mythology, & his stylistic choices in the handling of the hero craft a new psycho-social role \\
Roguery. & of picaresque mythology.
\end{tabular}

\section{INTRODUCTION}

Soyinka's poetics, coupled with his thoroughness in pursuing what Gibbs (1980) describes as "the aesthetic matrix" (p. 9) being the fountain of his creative inspiration and his genius, as manifested in his dramatic works, make him not only a towering figure in African literature but they combine to carve a niche for him as a productive artist actively engaged in redefining the models of literary classicism. His creative works draw upon mythic and archetypal elements that reflect the universality of the human experience while simultaneously portraying the realities of his socio-cultural environment, especially his Yoruba background. In The Bacchae of Euripides: A Communion Rite, for example, Soyinka utilizes the Greek myth in his play, both as an adaptation of Euripides' The Bacchae and a re-interpretation of the Dionysus myths. He also utilizes the Greek Orpheus myth in the construction of his novel, Season of Anomy, in which he employs complex imagery refashioned from allusions to Greek matricidal myths. This essay sets out to examine how Soyinka appropriates the universal archetypal figure of a trickster in one of his comic plays to reflect both the universal thoughts shared in the psychic inheritance of humanity about the trickster image and his domestication of the image as a manifestation of the socio-cultural realities in his society.

\section{LITERATURE REVIEW}

One of the recurring dominant archetypes which have continued for centuries to appeal to writers of all ages, including Soyinka, is the fox figure utilized in beast fables, epics, and analogies to reflect both the wily, clever, and predatory nature of humans on the one hand and the witty, humourous rogue on the other. Both characteristics of the fox figure have been exploited by Soyinka (and other literary artists) to express the universal theme of voracious greed with the intent of examining to what extent humans exhibit the fox's cunning and traits, and also to find out how such a character either positively or negatively reflects the ethos of a particular given society. Soyinka's portraiture of the fox figure in two of his comic plays, The Trials of Brother Jero (1964) and Jero's Metamorphosis (1973), manifests an ambivalence in the heroes (Brother Jeroboam and Jero, respectively), which confirms the view that the archetypal hero is "the most paradoxical of all characters" (Abrahams, 1968, p.170). Since the 
fox image combines the attributes of many other types of trickster traits such as a clown, a fool, a cheat, a jokester, an initiate, an ogre, and other times a culture hero, Soyinka manipulates the heroes to exhibit a transcendental or archetypal characteristic of the human psyche similar to Radin's (1972) description of the trickster as a ubiquitous and "inchoate being of undetermined proportions, a figure foreshadowing the shape of man" (p. xxiv).

In fact, Carroll (1984), citing Jung (1970), suggests that the ubiquitous nature of the trickster image in folktales portrays the image as an "archetype buried in the mind of all human beings" (p. 105), establishing its universality within the archetypal literary criticism postulated by Frye (1957). Frye's suggestion of the archetype as a recurring pattern, or a "symbol which connects one poem with another" helps to unify and integrate the literary experience which sees those patterns as a product of certain "elemental and universal forms [buried] in the human psyche, whose effective embodiment in a literary work evokes a profound response from the attentive reader", primarily because the reader also shares the archetypes conveyed by the author (p. 99). Jung (1961) also explains that "archetypes are not inherited ideas or patterns of thought borrowed" (or imitated) from other cultures, but they "represent inherited forms of psychic behaviour" among humans (p. xvi). He maintains that these psychic instincts are "older than historical man ... have been ingrained in him from earliest times, and, eternally living, outlasting all generations, still make up the groundwork of the human psyche. It is only possible to live the fullest life when we are in harmony with these symbols; wisdom is a return to them" (p.42). Soyinka's return to these tropes as motif in the plays, mentioned above, follows the universal trend of assigning the trickster figure the conventional roles of a trickster who entices its "victims" or "partners" with deceit and cunning in order to gain personal comforts or selfish ends. Indeed, the victims of the trickster are always portrayed as dupes and dunce who exhibit the base nature of humanity. However, the artist's stylistic modes devise a new role for the trickster figures.

Soyinka's handling of these heroes suggests some positive inherent qualities associated with the fox trickster figure: a creative mind, a 'readiness' to deal with society's infractions and lack of discretion, and a determined will to regenerate and order society on the acceptable mores. These positive attributes become the emblems to suggest the ambivalence and paradoxical nature of Soyinka's archetypal trickster fox drawn from his socio-cultural environment. In Yoruba metaphysics, the fox is seen as an elusive, slippery creature whose operations mostly manifest in the night. Afejuku (2018) suggests that the Yoruba venerate the fox because of its deep and subtle mind, which aids it to entrap its victims unawares. Its ways are unknown to skillful hunters, and this explains why warriors are warned never to depend on or trust those who wear fox hides. Soyinka reconstructs the archetypal fox image of the trickster, as expressed in Yoruba ontology, to showcase the inmost patterns of the ambivalent nature of humans in dealing with the eccentric behaviours of humanity.

\subsection{Research Questions}

This essay sets out basically to examine how Soyinka utilizes the universal archetypal trickster figure in one of his comic plays to reflect both the universal thoughts shared among humanity and his domestication of the image to reflect the socio-cultural realities in his Yoruba society. Specifically, this essay seeks answers to the following questions:

1. In what ways does Soyinka's artistic choices in the play reflect both the universal posturing of the trickster and the ethos of his immediate Yoruba society?

2. How different is Soyinka's handling of the trickster to uncover the new psychosocial role of the trickster in the African society?

\subsection{Significance of the Study}

This essay examines Soyinka's portrayal of the trickster hero and how his stylistic modes, as utilized in The Trials of Brother Jero, establish ways through which the hero creates good out of chaotic situations; a concept Radin (1972) describes as a "picaresque mythology" 
(p. xxv). Such a hero is not guided by the moral codes of society or the normal conceptions of good or evil, but he is repulsively highly promiscuous and unpredictable to make possible what I will describe as creating "order" in a "disordered" society with intent of ultimately bringing culture and civilization to humankind.

\section{METHODOLOGY}

Since the study is focused on Soyinka's dramaturgy in the play The Trials of Brother Jero, and how he employs tropes from the Yoruba tradition to reflect his view of the archetypal trickster's new role in society, this essay utilizes the qualitative mode of literary analysis to study the dramatist's stylistic modes. Hence, the essay is structured into four main segments. The first examines Soyinka's utilization of the universal archetypal hero and how he domesticates the choice to reflect the realities of his immediate society. The second and third segments explore Soyinka's stylistic modes and how he utilizes these to manifest human eccentricity, as demonstrated in his humour theories. The fourth section takes a look at Soyinka's epistemology on the role of the archetypal trickster hero in dealing with human folly and eccentricities, and in the process highlighting the dramatist's artistic vision for society.

\section{RESULTS AND DISCUSSIONS}

\subsection{The Archetypal Posturing}

Soyinka's choice of the fox image to portray the trickster figure in The Trials of Brother Jero (The Trials ... for short) manifests his archetypal posturing in refashioning certain shared beliefs among people of West African descent regarding the conception of the popular trickster hero. Such trickster triumphs due to his cunningness, shrewd behaviour, and an avowed predisposition to succeed despite the chaos his actions create. Some common examples of such tricksters include Ananse (among the Akan in Ghana), Legba (among the Fon people in Benin), Ogo-Yurugu (among the people of the central plateau region of Mali and the people in Burkina Faso), Eshu-Elegbara (among the Yoruba of Nigeria) and in Central Africa, Ture (among the Azandes of Sudan). These tricksters are always portrayed, as Hynes (1997) describes them, "an out person" because their actions are often "outlawish, outlandish, outrageous, out of bounds and out-of-order" (p.34). They normally move quickly and selfishly across all boundaries in society with virtual freedom, with the sole aim of satisfying their ego.

In The Trials ..., Soyinka creates his hero, Bro Jeroboam, (Jero, for short) to reflect the trickster "out-of-order" fox who shares kinships with the philosophical content of one of the revered gods among both the Yoruba people of Nigeria and the Fon people in Benin. The dramatist, in crafting the play, focuses on the idiosyncratic personality of Eshu-Elegbara, (or Legba) whom most West African people, according to Davis (1999), ascribe cultic rites through "spiritual communication, divination and the peculiar chaotic" sensibilities of the trickster ( $p$. 45). Davis intimates that Eshu-Elegbara (shortened as Eshu) is "a divine mediator of fate and information, a linguist, and a crafty metaphysician" (p. 47). He is a swindler "not just because he fools people and creates chaos", but more intensely because he is constantly breaking the very codes of society he is expected to enforce (p. 47). Ironically, though Eshu provides society the insight into Ifa's operations, he does not prescribe acceptable moral conduct because he is constantly "flowing through the cracks of fate" (p.47). In addition, Eshu manifests a spiritual connection between chaos and complexity of exchange, making him a god with varied stories, moods, and lusts. Within the West African tradition, especially among the Yoruba, Eshu, therefore, becomes a personification of principles that are tangible when they are integrated into the fabric of everyday living to reflect human behavior of the craze for money, family, sex, power, and language as emblematic features of a people's culture.

Eshu consequently possesses what Carroll (1984) describes as "enormous sexual appetites," which apparently explains humans' insatiable greed and inordinate evil concupiscence. (p. 110). This is made concrete in the metaphysics of the Yoruba people who, according to Davis, "hold Eshu responsible for acts of adultery and illicit sexual relations 
generally. The long pigtails which are typical of the hairstyle associated with Eshu are often carved in the shape of a penis on statuettes of Eshu" (p. 49). The obvious association between Soyinka's trickster figure, Jero, and the Eshu personality in the oral tradition of the Yoruba is evident in the dramatist's vision of portraying varied manifestations of the human condition through the popular mode of the comedic genre to reflect a society in which roguery, deception, gulling is an "acceptable norm", and one motivating force in human action is insatiable greed.

The dramatist valorizes this greed in humans (in the play) to reflect the manifestations of the socio-economic imbalance in his immediate society, which apparently became increasingly individualistic and self-centered. The emergence of capitalism coupled with the economic transformation in Nigeria during the mid-forties created a growing feeling of pride and nationalism among the citizenry, especially in the lives of the emergent middle class to the neglect of the marginalized and impoverished masses. There was a marked improvement dramatically in all aspects of life among the elite - education, health, and social infrastructure.

Ekundare (1973), in An Economic History of Nigeria 1860 - 1960 provides a detailed account of the socio-economic activities in Nigeria, and traces how the society had transitioned from a purely agrarian to a market economy which tended to romanticize individual ambition. Educational facilities had improved greatly, and increasing numbers of Nigerians were educated outside the country resulting in the emergence of an educated elite class of lawyers, doctors, administrators, politicians, and other professionals who advocated and participated in both the political and economic reforms of the country. Ironically, the Nigerian Federal Government, which was expected to expand the resources to bring improvement in the provision of infrastructure, training programs, and general services that will benefit the masses, became excessively greedy and looted the country's resources for their personal gains.

These naturally created an imbalance in society since everyone was interested in actualizing the popular cliché at the time of independence, to "chop a big slice of the National cake" (Rotimi, p. 4). The spirit of competition, scrambling for resources, and avariciousness manifested in all aspects of society. Obviously, these developments served as a rich source of materials for literary artists. Achebe's A Man of the People, Ekwensi's Jagua Nana, Rotimi's Our Husband Has Gone Mad Again are good examples of the artistic portrayal of the socioeconomic malaise which plagued the Nigerian society.

In The Trials ..., Soyinka manipulates the effect of the socio-economic malaise on both the middle-class elites and the majority poor to create a kind of tension between the individual and society. For the middle-class, their desire to maintain the status quo leads them into a further destructive exhibition of greed which ironically plunges them into the condition of buffoonery, daftness, and outright stupidity. On the part of the masses, the tension generated unnerving anxiety for them to change their socio-economic statuses by annexing society's cherished values and instituting a new lifestyle of roguery, lies, deceit as a means of actualizing their fundamental desires.

Soyinka exploits the boundless energies exhibited by both groups to create a titillating and exciting but also extremely disturbing society of mischief, mistrust and fraud to produce a new order of greed in contemporary Nigeria. This socio-economic background against which Soyinka crafts his play justifies the roguery trade of Brother Jero and the other charlatans in the Nigerian society. In Soyinka's artistic world, the dire economic conditions of the marginalized poor compel them to find solace in religion, which obviously, as the Marxian theology instructs, became the opium to soothe their egregiousness and also to initiate the roguery trade.

The dramatist provides a cynicism of contemporary society in the activities of the new religious federations and Christian crusaders whose rampant denominationalism by the 1960s at the Lagos Bar Beaches created not only avenues for the roguery trade among the churches but also became a subject of ridicule. The hero in his play is described as the "Articulate Hero of Christ's Crusade" (The Trials..., p.19). Jero exhibits a lifestyle craft of pulling a prank on 
both the emergent middle-class people and the ordinary masses. He is an egotistic rogue who is driven by greed and an insatiable sexual appetite for "the daughters of Eve." From the beginning of the play to the end, Jero is presented as a self-acclaimed master prankster whose skills in deception and sheer roguery excite the reader rather than repel him. He is also a selfstyled knave who knows how to manipulate his clientele to achieve his sole aim of keeping them always "dissatisfied people" who keep coming to him (The Trials..., p.20). For his philosophy of the trade suggests, "once they are full, they won't come again" (p. 20).

In fact, his capacity to deceive both the highly placed middle-class and the commoners, keeping them always in an expectant "better tomorrow" mood, and his irrelevant fleecing of their resources for his personal comfort take on a significance in the play as the dominant imagery the dramatist uses to develop his trickster hero. Soyinka invests his hero with moral laxity, like the Eshu figure in Yoruba cosmology that makes him the antithesis of a true religious leader, a kind of a free agent liberated from all the restraints; that regulate the "prophetic trade." In addition, Jero is endowed with the intelligence and cunningness to outthink most of the characters, who rather pathetically exhibit the gullibility in humans at the hands of tricksters. In the exercise of this intelligence and craft, the trickster exhibits his ability to move the action of the play.

Soyinka's The Trials ... portrays a society that seems to be sinking under a yoke of insatiable yearnings and greed for materialism arising from the socio-economic realities in Lagos during the early 1960s. The rich, the poor, the professionals, even charlatans, and all categories of humans seek after the tangible and intangible articles of human existence through the medium of religion with the sole intent of transforming their marginalized positions in life also to crave for limitless desires. Society's cherished values as exhibited in intelligence, common sense, hard work and perseverance as the best qualities that guarantee success and socio-economic change in one's status (in life) have been buried under the cold logic of seeking the divine. This cold logic is portrayed in the play through the fake churches spluttered along the beaches in Lagos. In the play, Jero tells us that "You have probably seen many of us on the streets, many with their own churches, many inland, many on the coast, many leading processions, many looking for processions to lead" (The Trials..., p.9).

The dramatist uses the proliferation of the prophetic trade and the internal wrangling for customers to provide an exploration of the socio-economic imbalance and as a metaphor to portray the ills in the Nigerian society. Chume, for example, after several years in the Civil Service as a Chief Messenger does not go to work. He seeks respite in prayers as a means of actualizing his potential first as an assistant prophet, second as an economically decrepit man, and then as a husband who so desires to beat his wife.

In the invocatory prayers he offers on behalf of the congregants, Chume reveals the incessant yearnings of the plight of the ordinary masses and their limitless desires for materialism. He intones thus:

... Tell our wives not to give us trouble. And give us money to have a happy home. Give us money to satisfy our daily necessities. May you no forget those of us who dey struggle daily .... I say those who dey push bicycle, give them big car tomorrow. Give them big car tomorrow, give them big car tomorrow, give them big car tomorrow (The Trials..., p.29).

The rhetoric as presented in the prayers between the now of "today" and the prospects for a better "tomorrow" do not only express the indexes of the yearnings of society but reflects a craze of society's indulgence in stupidity and lazy attitudes which naturally create a situation where gulling and the roguery trade thrive in society.

The dramatist's vision therefore is to justify the legitimacy of the existence of rogues and tricksters in society like the ubiquitous presence of Eshu-Elegbara in society. These rogues 
and tricksters always win the moral battle against society and mesmerize it with their antics and cunning. In addition, society's inability to restrain its inordinate cravings for materialism within the corrective reasoning of work ethics predisposes it to gullibility and the subsequent duping by the rogues.

\subsection{The Archetypal Knavery and Gulling Mode}

Soyinka devises a structural pattern which provides a system in which the hero (in concert with his parasite) acts as a knave to deceive and defraud individuals who invariably are portrayed as dupes or dunderheads and unthinking. The capacity of the knave through wit, subtlety and flattery to outwit the gulls is the essential quality of Soyinka's comedy in portraying human predatoriness and folly. This skill of the dramatist creates the impression that humans readily degenerate into beasts and irredeemably lose their distinctive humanness or virtue. To ensure the artistic success of this scheme, Soyinka designs the roles of the knave, Jero (who plots the mischiefs and roguery), and the dupes (who exhibit stupidity and buffoonery) to reflect the social realities of the West African society where crime and indecent behavior have become the modus operandi of modern-day churches. He sustains the reader's interest in this vision by implicating the reader to become active participants in Jero's roguery. He makes Jero to address the reader directly to believe in the idea that he is "a prophet by birth and by inclination." In addition, his insignia of the Biblical Nazarite vocation of a "rather thick and long hair" flowing down to his eyes and neck proves that he is ordained a natural prophet (p. 1). Jero confides his secrets of the trade with the reader and prepares to con us into conspiring with him to dupe the gulls in the play.

Soyinka's craftsmanship in portraying the gull-knave pattern manifests the hero's selfconfession of his roguery intent and his avowed position of not only duping his old master but also duping society. The reader is subconsciously invited to witness how Jero will execute his tricks on his victims since he appears time-bound. Jero has to execute this assignment very quickly because an audience is ready to gulp down his antics. The dramatist crafts a short fivescene play that cuts out details of the roguery activities of the hero and bridges the gap between the hero and the reader. This skill makes the reader complicit in the hero's knavery and also psychologically prods the hero to exact more roguery on the dupes since the audience is ready to believe whatever Jero tells them rather than they witnessing it.

The dramatist, therefore, does not provide detailed accounts of Jero's interactions with the gulls but makes the hero recount his roguery escapades and false prophecies to the reader. The first gull is a man whose status in society is not indicated. He is predicted to be "a chief in his hometown" only when he "lives to be eighty." Perhaps, this unnamed character shares some similarities with Jonson's Corbaccio in Volpone, an octogenarian who still has hopes of surviving a younger legator to inherit Volpone's wealth. Soyinka's interest in this "safe prophecy" is to portray the gullibility of society at the hands of these rakes and false prophets. The dramatist uses this event to portray his criticism of the religious charlatans in society and modern-day nascent capitalism that has invaded our chieftaincy institutions and robbed them of their former glories. In West Africa, most people use the money to buy their way into the revered and sacred chieftaincy institution.

The easily identifiable trait among the dupes is their inability to think and act reasonably to commensurate with their social standing in society. They exhibit the dunce and bizarre posturing in humans striving to rid themselves of stupidity, but in reality, they manifest themselves as fools and buffoons. Soyinka provides a good example of such a dupe character in the personality of the Second Faithful, whose idiotic behaviour bears a semblance to someone of high repute. However, he manifests the traits of a fool. Here is a man who strongly believes that he would be the first "Prime Minister of the new Mid-North-East State - when it is created" (The Trials ..., p.25) because a prophet has predicted it. Common sense dictates that a "Prime Minister" is normally the leader of the majority in Parliament to form a ruling 
government. However, it is not a position that one can get out of the ordinary, not even from prophecy. Hence to firmly believe such a prophecy manifests the idiocy and stupidity of the socalled leaders of society. The artist exploits modern-day Christianity's weaknesses, especially politicians' over-dependence on so-called prophecies to criticize the mental opacity of leaders whose self-abasing and self-deluding characteristics define their degraded worth and buffoonery status.

Soyinka's skill ensures that these leaders are cozened by rogues (such as Jero) who rather exhibit superior wit and intelligence to rule society. In Scene Five, the dramatist provides a graphic portrayal of the "Honourable Member of the Federal House, a back-bencher" who apparently is aiming at a ministerial position in government. The Member's daftness and greater gullibility amazes the reader who had been made complicit with Jero to execute the knavery. This man we learn carries "a sheaf of notes in his hand" delivering "a fire-breathing speech" but the reader cannot hear it (p. 38). The portrayal of the Member's vulnerability and gullibility is manifest in his inability to make the speech despite the fact that he rehearses it every day. It suggests the dunce posturing of leaders who are too scared to act and most probably why they fall victims to rakes like Jero. The Member's inability to exercise prudent judgement in discerning the bait of the "Minister for War" thrown at him, in a country which is not plunged into strive (even if it were so, one will rather expect a portfolio of a 'Minister for Peace'), and his indiscretion in assessing his own leadership qualities make him a victim of Jero's roguery. Jero quizzes him thus: "But are you of the Lord? Are you in fact worthy? Must I... pray to the Lord to remove this mantle from your shoulders and place it on a more Godfearing man? ... Brother, are you of God or are you ranged among his enemies ...? (The Trials ..., pp. 40-41). Jero had earlier informed the reader that the "revered" legislature is already a victim of his roguery trade, and he invites us to watch him exact his antics on him.

The series of rhetorical questions flung at the Member, his crouching posture before Jero, coupled with the dramatist's skill of blending Chume's pursuit of Jero (brandishing a cutlass to kill him) and Jero's constant 'appearance' and 'disappearance' in his dealings with the Member of the Federal House serve the artistic aim of satirizing one of the key institutions of governance (the elected representatives of the country) whose blindness and daftness manifest in the kind of atrophied religious solutions they proffer in solving the myriad of problems confronting Africa. The Member interprets Jero's sudden "miraculous disappearance," occasioned by Chume's murderous pursuit, as a visitation of the divine. He believes that he "must await his [the prophet's] return," for if he truly "show[s] faith, he will show himself again. ... Perhaps he has gone to learn more about this ministerial post" (The Trials..., p. 43). The gullibility of this "nincompoop" (as Jero describes him) testified to by his actions of removing his shoes (with the belief that the place was a holy ground) awaiting the return of the prophet suggests not only Soyinka's outright criticism of political leadership in Africa but their absolute dependence on the providential supply of the divine instead of exercising discretion and intelligence to governance issues.

In The Trials ..., Soyinka's satirical jibes are not so much directed at the trickster as at the society, which is obviously open to exploitation by its folly and stupidity. He portrays a society in which we observe a cross-section of both the supposed upper classes and the lower classes shamelessly gulled by the roguery of the trickster Jero. All the dupe characters in Soyinka's play: The Member of Parliament, The Prospective Chief, The Penitent, The Prospective Prime Minister and even Chume - are invested with a common motive and a purpose of changing their socio-economic status in life (which in itself is not a bad motive), but their resort to the lazy-easy-way approach portrays them as easy prey for gulling. Since Jero has been aligned with Eshu (as the oral narratives of the Yoruba cosmology suggest), he persistently resolves to set the affairs of society in order by offering to be what Pemberton (1975) describes of the trickster as "the road maker" and the "messenger" for many, through its spiritual characteristics of communication (p. 25). 
As "the road maker," Jero's greatest asset is his power of communicating his truest intents to the reader. He creates a path for humans to interact with their self-actualizing bid. He employs his tongue and wit to manipulate all the dupes to his advantage. His capriciousness, good appearance and dexterity of body and mind are all features he shares with Eshu. In the oral traditions of the Yoruba, Davis (1999) suggests that Eshu is acknowledged as the messenger in Orisha rituals. No human can interact with the divine except through him. Consequently, "one must feed or call him first before any other gods are invoked" (p. 50). The preeminence of Eshu is therefore manifest "through his linguistic ability", his skill at communicating both the aspirations, hopes and the danger of humans: hope because humans come to him in full expectation of being aided; and danger because he plays trickeries with the evidence he has about humans to keep them continuously gulled and to establish the fact that he oversees the network of exchange (p. 50). The suggestion therefore by Pelton (1980) that Eshu's nickname, Aflakete, which means "I have tricked you" is quite appropriate (p. 72).

Soyinka exploits this piece of Yoruba metaphysics in developing the gull-knave structure. The dramatist invests the knave, Jero, with an outstanding quality of wit and intelligence. This is best displayed in the hero's linguistic ability to take advantage of the depraved mental conditions of his dupes whose buffoonery and daftness attract the dramatist's censure.

\subsection{The Skill of Oppositional Disguise in the Structural Pattern}

In developing the structural pattern of the intrigues of the trickster within the gull-knave pattern, Soyinka switches the roles of the knave(s) and the gulls to exhibit a kind of oppositional disguise. Jero at several points in the play is presented as the master crafty communicator rogue who fleeces his clients (or "customers" as he describes them) as a means of enriching himself but as some points he exhibits the lawlessness and buffoonery manifested in his unrestrained sexual appetites which he considers "a very cheap curse" invoked on him by his Master. In the main action of the play, Jero is aided by Chume, his assistant (though also a gull), to defraud society. In these scenes, he appears as a master schemer over-running his dupes with ecstatic amusement through the religious services and prophetic utterances he gibbers. However, the scenes: where he jumps through the window to escape paying his debt to Amope, his inability to control his libido as he daily lusts after the Young Girl and savours "the exposed thighs" of the Woman pursuing the Drummer Boy during the climax of the service, and the resultant beatings he received at the hands of the Woman portray him as a glorified buffoon. In addition, in the final scene where Chume chases Jero with murderous intent while brandishing a cutlass after him, Jero plays the role of a buffoon. He condescends into a moribund and ghoulish state that evokes the reader's anxiety and fear. However, Jero recovers from the momentary fright as he transposes his buffoonery to the Member of the Federal House who really exhibits the posturing of a dunce.

The dramatist wedges these oppositional disguises into the personality of Jero to ensure that there is wit in deception and there is grandeur in changing roles to simulate the prankster figure of Eshu-Elegba. Despite Amope's watchfulness and vigilance to expose Jero as a debtor and a fake prophet, coupled with the Penitent's eagle eye on Jero (regardless of her 'selfabasing convulsions' and paroxysms) and Chume's near-sanity revenge on his master, Soyinka deliberately subsumes all these efforts and manipulates all the characters and situations to change with exhilarating rapidity, confusing all relations and initiating a disfigured portrayal of humans in consonance with the Yoruba ontology of Eshu. The trickster then acts as the leading cause of disturbances, disorders, disasters, and improprieties. All resemblances of what is considered truth and false are subject to his rapid alteration, and his lies, deceit, cunning, and crookery derive from the trickster personality he has been clothed with.

Davis (1999) recounts a famous Yoruba story about Eshu's escapades concerning two intimate friends who pledged undying devotion to each other but disregarded the power of 
Eshu. These two friends work in opposite fields. The account of the story has it that Eshu leisurely walks on the boundary between the fields wearing a hat that is black on one side and red on the other. While walking, he exchanges brief conversations with the two friends. After the day's work, both friends discussed the visitor wearing the cap. They ended their conversation with a vicious quarrel about the color of the man's cap, insulting each other as crazy, dumb, and blind. It took the timely interventions of neighbors and the arrival of Eshu himself to stop the fight. After the two friends had explained their quarrel, Eshu displays the two-sided hat with the intent of chiding them for not acknowledging him first in their interactions. The moral of the tale suggests that Eshu moves along the crest of two different world views, obfuscates communication, exposes ambiguity of knowledge, and plays with varying perspectives to initiate disorder in society. However, ultimately, he re-appears to institute a semblance of order. Soyinka exploits this piece of Yoruba myth about Eshu in his depiction of Jero.

\subsection{The Epistemology on Picaresque Mythology}

Soyinka's conception of his hero captures notions of similar affinities with the Eshu personality in his portrayal of the scenes where Jero interacts with the couple, Chume and Amope. The series of innuendoes, disagreements, verbal abuses, and battering that erupt in their marital relationship may be attributable to both their depraved socio-economic condition and their irreverence to the power of the Jero figure in their lives. Amope's persist in retrieving her debt from Jero and Chume's insistence on getting permission from the same Jero to beat his wife initiate a system of disorder in the prophet, who later learns of their relation. Soyinka's skill exploits the Eshu concept of wearing a cap in two color shades metaphorically to translate that fright into mental energies to create disorder in the Chume-Amope relationship synonymous with society's conditions.

Jero's decision to allow Chume to beat his wife serves two artistic purposes. First, it provides him the best option to deal with a garrulous creditor, and second to initiate a similitude of 'order' in the marital relation between the couple. Ironically, the couple is unaware that Jero is the self-same cause of their disordered life. When Chume gets to know of the truth at the point of executing the semblance of 'order' in his marriage, Amope calls upon the same Jero to salvage her from the distraught husband. By the end of the play, Jero arranges with the police force, supported by the buffoon Legislature, to commit Chume to a lunatic asylum for a year. What really happens to Amope is unclear to the reader. But we can guess that Amope will surely find respite and 'order' to be the prophet's lover, as Chume suggests.

The imagery of 'order' and 'disorder' in the gull-knave pattern as Soyinka contrives it enables the knave, Jero, to prevail over the gulls not because of his superior moral insights but because of the excitements of creating a trickster tale in which human gullibility is exposed and criticized. Jero is presented as the scourge of the idiocies of the gulls, and he seems to be chiding the inadequacies of society, its indulgence, and the anatomy of the time's abnormality wherein humans place value on the acquisition of wealth, power and materialism. These gulls employ the easy-lazy-path approach to the neglect of pursuing traditional acceptable values like honesty, hard work, intelligence and truthfulness. For example, Chume goes to work only to report sick and leaves for church with the intention of gaining permission from the prophet to beat his wife as a means of assuaging his demented and disordered life instead of focusing on improving his socio-economic status. Though portrayed as an intelligent woman, the Penitent Woman does not apply corrective reasoning in her quest to mother children. Rather, she chooses to engage in her glossolalia freak of "Echa, echa, echa, echa, echa...ei, eei, eei". The dramatist's attribution of the adjective "faithful" to her absurdity and meaninglessness in her mannerisms and glossolalia further portray the criticism. The Member of the Federal House also does not know the basic rudiments of speech making and communication. Instead of 
seeking scientific methods of dealing with the disorder in his life he resorts to the easy-lazypath and falls a victim to the rogue.

The resourcefulness of Soyinka in crafting a trickster tale in which Jero contrives ways out of difficult situations and acts mischievously to exploit human weaknesses as a means to prosper exhibits the skill of a good dramatist, who is following after the comic tradition creates a scheme to reflect universal forms. He understands that knavery and gulling are the ingredients for the workings of the comic law that regulates the construction of a good comedy, and also a dramatist's skill of consciously creating doubtful lingering moral issues and perverting them to make the trickster prosper in work generate the joys of artful intrigue that the reader admires in the hero.

Soyinka's stylistic mode in the play which enables the reader to identify with the rogue whose brilliant deceptions and compelling use of superior wit and sheer audacity in manipulating events and situations transposes the reader into an ecstatic joyful comic mood. The reader of Soyinka's play enjoys the successes chalked by Jero in his interactions with the gulls. There is a level of momentarily satiation in pure knavery as we align ourselves with the daring ventures and near-escapes. We are compelled to desire more of Jero's intrigues. Psychologically, we "prod" him even to greater heights of dangerous moves as we witness the concluding scene in which the revered Legislature wakes from his slumberous nincompoopery "with a start, stares open-mouth, and falls flat on his face, whispering in rapt awe, - 'Master"" (The Trials..., p.44).

There seems to be an implicit request from the Federal Member for more roguery to be exacted on him as he awaits, barefooted, further instructions from Jero on the supposed "holy ground". Soyinka's art, however, recognizes the moral ambiguities involved in the artistic world especially considering the criminal schemes of the trickster hero. Soyinka's skill compels the reader to soberly reflect on what kind of "justice system" the artist is portraying, especially when we consider the pathetic plight of Chume and his moralizing cry at the end of the play: "O God, wetin a do for you wey you go spoil my life so? Wetin make you vex for me so? I offend you? Chume, foolish man, your life don spoil. Yeah, ye...ah ah, ye-e-ah, they did ruin Chume for life... ye-e-ah, ye-e-ah ..." (The Trials ..., p.42).

The dramatist's scheme implicates the reader, who is made to both share in the blame game where divinity and society combine forces to "spoil" the life of Chume. At the same time, Soyinka's skill ensures that the reader detaches him/herself through sober reflection of the weaknesses of State institutions mandated to deal with crime. Jero's confession to the reader that he will exploit the influence of the nincompoop Member of the Federal House to secure a one-year judgement from the judiciary to commit Chume to a lunatic asylum manifests a criticism. The import of the artist's skill implicates the three main governmental institutions of State (the Legislature, the Executive and the Judiciary) which have the responsibility of maintaining law and order in society, and throws into relief the moral question of the role of legal codes or values in contributing either positively or negatively to the well-being of humans; since on the one hand, Chume feels duped and on the other hand Jero feels secured and protected. The dramatist seems to suggest that these institutions are there to provide support for those who know how to manipulate men and institutions for their advantage. Since society itself is gulled as demonstrated in the metaphor of Jero's NEIGHBOURS affirming that Jero is a 'good prophet' who solves all manner of ailments afflicting humanity: Chume's foolishness, Amope's garrulous loud mouth and the Legislature's stupidity, there is a sustained reasonableness in Soyinka's quest to institute a kind of a "justice system" in the play.

The Soyinkan "justice system" exhibits a patten in which the rogues become instruments in the hand of the dramatist to exact a kind of judgement on the gulls. The dramatist initiates reductive posturing of the gulls in the scenes where Chume is emasculated, insulted, and reduced to the vermin gypsy of the worst sinner and a "harbourer of Astoreth" who must demonstrate his beastly nature in the glossolalia choruses. In addition, Soyinka's rogue, Jero, by virtue of his superior wit, adopts superior verbal agility and higher intelligence to exact a 
reductive and dunce posturing in the Member of the Federal House and the prospective Prime Minister of the Mid-North-East State.

The dramatist of The Trials... provides a similitude of a kind of justice system in which the harsh moralism is subverted and the reader, rather, is urged to admire the vigour of the rogue's trickery. Soyinka makes the reader endorse the roguery activities of the knave to glorify wit and intelligence over moral virtues. This view is made concrete in the play because the adjudicators of moral virtue themselves (as symbolized in the three central governmental institutions of state) are clothed in a perverse formulation of criminality as dictated by the pessimism and sensitivity that has engulfed the social economy of most African countries, specifically the Nigerian case in the late fifties, early sixties and beyond.

Ogbeidi (2012), in an essay, "Political Leadership and Corruption in Nigeria since 1960: A Socioeconomic Analysis," examines the correlation between the manifestation of corruption among the political leadership class since the 1960s and its implication for the socio-economic development in Nigeria. He argues that depraved political leadership coupled with the malicious effect of corruption on public institutions as a whole since independence is the resultant consequence of the institutionalization and deification of roguery and corruption in Nigeria. In addition, it has also led to a new kind of social economy which celebrates wit and intelligence on the part of the ruling class.

Soyinka's portraiture of Jero's wit and intelligence over moral virtue as the verdict in the play reflects the socio-cultural realities of a society he knows so well, glorifying creative ingenuity and "smartness." The portraiture also provides the opportunity for the dramatist to execute a savage judgment upon a lazy, self-seeking, and corner-cutting society whose imitation of a kind of justice rests only in the bosom of the very intelligent and clever hero who decides what is best for society. Jero's determination of what is 'good' for society is perhaps similar to the sensibilities of the Yoruba god, Eshu.

According to Davis (1999), Eshu is "the god who has access to ashe,", which literally means, "so be it," a metaphorical endorsement of what is admirable in society (p. 54). He recounts the story of how Eshu gets ashe' when all the deities trek to the supreme being, Orunmila, to ascertain who among them is the next most powerful. Each deity carries a gigantic sacrifice on its head, but Eshu consults the supreme being and gets to know that he only needs to carry "a bright red feather set upright on his forehead" (p. 54). When Orunmila sees this, he bestows on Eshu the power of ashe' since Eshu had shown his repugnance to carrying loads, as well as his discretion to the handling of information. The story explains why Eshu statuettes often have a large priapic curl or nail on the head to this day. It confirms the proposition that one of Eshu's characteristics shows humanity, in the view of Thompson (1983), to "cultivate the art of recognizing significant communications" of wit and intelligence, the point where doors open or close for individuals who will have to make decisions that will affect them perpetually or forever lose the opportunities (p. 19).

Jero has truly recognized the power of effectively communicating to both his audience and his gulls. He has demonstrated significant wit and cunning to perform whatever promise (prophecy) he issues out, and by implication, assumes a deified midway posture of a 'godhuman being' to function as a cultural transformer. Soyinka's skill, therefore, places the "right red feather" of Eshu on Jero to institute the ashe' theology in the final episode of Jero's career as a trickster with minimal divinity status to create 'order' out of a disordered society. As Jero dismisses the nincompoop of the Legislature, he is crowned with "a ring of red or some equally startling colour [which] plays on his head, forming a sort of halo" to establish the norm of "so be it" in society (The Trials..., p. 44).

In the sequel to the Jero plays, Jero's Metamorphosis (1973), Soyinka dramatizes the same ashe ' principle in portraying the archetypal hero, Jero, who exhibits a higher level of wit, intelligence, and roguery. Jero's mastery of the communication skill coupled with his manipulative abilities of both humans and institutions succeeds in marshalling support from other beach fake prophets in the formation of a supposed united church (CASA) to "twist" the 
hands of governmental institutions to sign off a document that confers all state lands along the beach for Jero's personal use. The play ridicules leadership struggle (among both religious and political divides), deception and corruption among the elite and shows how state institutions are gullibly deluded by swindlers who always demonstrate their resourcefulness in displaying a higher dexterity of wit and intelligence.

Soyinka's skill celebrates the use of wit and intelligence for effective gulling of society's dupes and the illogicality among humans. The dramatist strives to fulfill partly a social reasoning working through the comic tradition and partly portraying a certain logic related to contemporary thinking about the nature of criminality in the twenty-first century. Soyinka's hero triumphs primarily because of his demonstration of a superior wit and showmanship in intelligence over the dupes whose exhibition of greed and self-seeking avarice translates their actions into a "crime" that must be "punished" harshly. The entire society is embedded in stupidity and an irrational quest for corner-cutting activities to actualize human greed, which automatically invites the execution of judgement from someone with a superior wit. Soyinka's summing of the human condition may appear harsh and may not rest on solid moral groundings, but the conclusion reflects the reality of society, a reality which valorizes intelligence and innovative ways, and by implication establishing those realities as admirable virtues.

\section{CONCLUSION}

Soyinka's art implicates a matrix of relationships within the comic literary tradition in portraying humans' absurd and ridiculous posturing. The trickster image in Jero's personality portrays him as a celebrated rogue created by the Divine Being as an externalization of a multidimensional figure (esoteric, divine, and human) assigned a sole purpose of effecting a change in society's outlook. The dramatist's deliberate manipulation of events at the end of the play to ensure that Jero is crowned with "a ring of red" (the metaphor of the god's signature and endorsement in consonance with the Eshu and ashe' theology in Yoruba metaphysics) and escapes unpunished, in spite of his roguery and dubious acts against humanity, enunciates the new role of the trickster. He is portrayed as someone who has the mandate to regulate the irreprehensible conduct of humans and supervise the realm where the illogical and irrational behaviour of society is mediated. Soyinka has demonstrated his commitment to the comic tradition, but also, he has exhibited his authenticity as a twentieth-century African writer who crafts a comic justice system that obviously reflects the spirit of his West African heritage.

\section{Implication for Educational Practice and Future Research}

Soyinka has demonstrated in most of his literary works and practice of criticism his unique skill of domesticating universal ideas and tropes to suit his immediate Yoruba society and serve certain artistic purposes. His choice of the universal trickster hero as the main trope in the play and the new role he assigns him opens a vista of new pleasures associated with the otherwise detested roguish trickster. It is therefore very important for teachers, students and general practitioners of the literary craft to approach (or appreciate) his works from this stand point rather than employ Western literary models as a basis to understand his works.

Further studies could be conducted on how Soyinka handles the ridiculous posturing of humans as exhibited in his other comic play, Jero's Metamorphosis.

\section{REFERENCES}

Abrahams, R. D. (1968). Trickster, the outrageous hero. In T. P. Coffin (Ed.), Our living traditions: An introduction to American folklore (pp. 170-178). New York, NY: Basic Books.

Afejuku, A. (2018, October). The fox in Yoruba mythology. Unpublished telephone discussion with the researcher. 
Carroll, M. P. (1984). The trickster as selfish-buffoon and culture hero. Ethos, 12 (2), 105-131 Davis, E. (1999). Trickster at the crossroads. ALBO, 4, 45 -57.

Ekundare, O. R. (1973). An economic history of Nigeria. 1860-1960. London, England:Methuen Publishers.

Frye, N. (1957, 2006). Anatomy of criticism. Toronto, Canada: University of Toronto Press.

Gibbs, J. (Ed.). (1980). Critical perspectives on Wole Soyinka. Washington, D.C.: Three Continents Press.

Hynes, W. J. (1973). Mapping the characteristics of mythic tricksters: A heuristic guide. In W.J Hynes \& W. G. Doty (Ed.), Mythical trickster figures. (Pp 33- 45) Tuscaloosa, USA: University of Alabama Press.

Jung, C. (1961). Psychological reflections. New York: Harper Touchbooks.

Jung, C. (1970). Four archetypes: Mother, rebirth, spirit and trickster. Princeton, USA: Princeton University Press.

Jonson, B. (1605, 1968). Volpone. London, England: Ernest Benn Publishers.

Ogbeidi, M. M. (2012). Political leadership and corruption in Nigeria since 1960: A socioeconomic analysis. Journal of Nigerian Studies. 1 (2), 1-25.

Pelton, R. (1980). The trickster in West Africa. Berkeley, CA: University of California Press.

Pemberton, J. (1975). Eshu-Elegbara: The Yoruba trickster god. African Arts. 9, 20-27.

Radin, P. (1972). The trickster: A study in American Indian mythology. New York, NY: Schocken.

Soyinka, W. (1964). The trials of brother Jero. Oxford, England: Oxford University Press.

Soyinka, W. (1964). Jero's metamorphosis. Oxford, England: Oxford University Press.

Thompson, R. F. (1983). The flash of the spirit. New York, NY: Vintage Books.

\section{$\underline{A U T H O R ' S B I O}$}

Nii Okain Teiko holds a PhD in Literary Studies. He was a Senior Lecturer at Methodist University College Ghana, where he taught courses in both European and African literatures, and some courses in Communication Studies. Currently, he has changed his institution of affiliation and he is with the University of Professional Studies Accra where he teaches courses in Communication Studies. His current areas of interest include a surrealistic study of the Ivorian poet and novelist, Veronique Tadjo, and the Influence of Jonsonian comedy in some West African dramatists' works 